\title{
IMPACT OF NITROGEN FERTILIZER LEVEL AND TIMES OF FOLIAR SPRAYING WITH POTASSIUM ON YIELD AND ITS COMPONENTS OF SOME FLAX GENOTYPES
}

\author{
Ibrahim¹, M.H.; M.E. Kineber ${ }^{2}$; A.Y. Ragab ${ }^{1}$ and W.F.M. A. \\ Galoo ${ }^{2}$
}

1. Agron. Dept., Fac. Agric., Kafrelsheikh University, Egypt, 2. Fiber CROPS Res. Dep., Field Crop Res. Inst., ARC, GIZA, Egypt

\begin{abstract}
Two field experiments were carried out at the Experimental Farm, Faculty of Agriculture, Kafrelsheikh University, Egypt, during 2013/2014 and $2014 / 2015$ seasons to find out the effect of nitrogen fertilizer level and time of foliar spraying with potassium fertilizer on straw, fiber and seed yields and its components of some flax genotypes. The experiment was carried out in a split-split plot design with four replications. The main-plots were assigned to flax genotypes (Sakha 1, Strain 402/1, Sakha 5, Strain 541/G/1, Sakha 3 and Strain 620/3/5). The sub-plots were allocated to nitrogen fertilizer levels (30, 45 and $60 \mathrm{~kg} \mathrm{~N} / \mathrm{fed}$ ). The sub-sub-plots were occupied with times of foliar spraying with potassium (spraying with potassium after 50 DFS, after 70 DFS and after 50 and 70 DFS). The obtained results could be summarized as follows:

- Sakha 1 cultivar produced the highest values of 1000 -seed weight in both seasons. Meanwhile, Strain 402/1 resulted in the highest values of seed yield $\mathrm{g} /$ plant in the second season. However, Sakha 5 produced the highest values of fruiting zone length, number of capsules/plant, number of seeds/capsule, number of seeds/plant, seed yield / plant (in the first season) and seed yield / feddan in both seasons. While, Sakha 3 cultivar resulted in the highest means of total plant height, technical length, straw yield/plant (in the first season) and straw yield/fed in both seasons. Strain $620 / 3 / 5$ produced the highest values of straw yield/plant in the second season, fiber yield/plant and fiber yield/fed in both seasons.

- Maximum means of all studied characters were produced from fertilizing flax plants with $60 \mathrm{~kg} \mathrm{~N} / \mathrm{fed}$., while the lowest values of these characters were obtained from plants that fertilized with $30 \mathrm{~kg} \mathrm{~N} / \mathrm{fed}$.

- Foliar spraying flax plants twice with potassium after 50 and 70 DFS significantly exceeded other studied times of foliar spraying with potassium and produced the highest values of all studied characters.

Form the obtained data in this study, it can be concluded that mineral fertilizing Sakha 3 cultivar, Strain 620/3/5 and Sakha 5 with $60 \mathrm{~kg} \mathrm{~N} / \mathrm{fed}$ and foliar spraying twice with potassium after 50 and 70 DFS from sowing could be recommended in order to maximizing straw, fiber and seed yields, respectively under the same conditions of this research.
\end{abstract}

Keywords: Flax, Genotypes, Nitrogen fertilization, Potassium fertilization, Yields 


\section{INTRODUCTION}

Flax (Linum usitatissimum L.) is one of the earliest plants that has been domesticated by humans and its production dates back to ancient history. Flax fiber is being blended with certain types of plastic resins to produce automotive components. Seeds from flax are crushed to produce linseed oil and linseed meal. In Egypt, flax is cultivated as a dual purpose (seeds for oil and stems for fiber). The cultivated area through the last 20 years was decreased from 60.000 to 30.000 feddan due to the great competition of other economic winter crops resulting in a gap between production and consumption. The gap could be minimized partly by increasing flax yield per unit area through sowing high yielding cultivars and optimizing the agricultural practices for growing flax among them nitrogen fertilization and times of foliar spraying with potassium fertilizer.

Sowing the suitable cultivar is important factor to enhance growth, yields and its components and quality parameters of flax. In this connections, Rahimi and Nourmohamadi (2010) indicating that there are significant differences due to flax genotypes in yields and yield components due to the differences in genetic structure and their interaction with environmental conditions prevailing during growing season. Khalifa et al. (2011), Al-Doori (2012), Bakry et al. (2012 a), Gallardo et al. (2014) and El-Borhamy (2016) indicated that significant differences were observed among the flax varieties in all studied traits, i.e. yield, yield components. Abd El-Mohsen et al. (2013) and Wadan (2013) found that the two tested flax cultivars; Sakha 1 and Sakha 2 exhibited significant differences for almost traits. Bakry et al. (2014) revealed that Letwania-9 and Evelen cultivars surpassed all other varieties in seed yield/fed. Blanka variety recorded the lowest values of straw yield/fed and biological yield/fed, while, Posna variety gave the lowest values of technical length. Abd Eldaiem (2015 a \& b) and Abd El-Dayem and El-Borhamy (2015) revealed that Giza 10 cultivar recorded the highest values of total plant height, technical length, straw yield/plant, biological yield/fed, straw yield/fed and long fiber yield/fed. Sakha 5 genotype produced the highest values of number of fruiting branches, seed yield/plant and seed yield/fed. Sakha 5 genotype exceeded Sakha 3, Giza 10 and Sakha 2 cultivars in number of fruiting branches, number of capsules/plant, seed yield (g/plant) and seed yield ( $\mathrm{kg} / \mathrm{fed}$ ). Barky et al. (2015 a) showed that Sakha 2 variety surpassed Amon in plant height, fruiting zone length, number of fruiting braches/plant, number of capsules/plant, seed yield/plant, straw yield/plant, seed and straw yields/fed. However, Amon variety surpassed Sakha 2 in technical stem length. 
Nitrogen is often the most important plant nutrients, which influences the amount of protein, protoplasm and chlorophyll formed, consequently increases cell size, leaf area and photosynthetic activity. The response of flax to nitrogen has been well established, as has the sensitivity of crop emergence and seed yield to seed-placed nitrogen (Lafond et al., 2003). Soethe et al. (2013) reported that nitrogen levels influenced plant height, number of capsules/plant, 1000-seed weight and seed yield/ha. Applying $45 \mathrm{~kg} \mathrm{~N} / \mathrm{fed}$, resulted in approximately an increasing in straw, seed and technological characters when compared with the effect of the lower nitrogen levels at 0 and $30 \mathrm{~kg} \mathrm{~N} / \mathrm{fed}$ (Mousa et al,.(2010). While, fertilizing flax plants with $75 \mathrm{~kg} \mathrm{~N} / \mathrm{fed}$ significantly increased all studied characters and produced the highest values as compared with control treatment (Abd El-Dayem and El-Borhamy, 2015 and El-Borhamy, 2016). Fertilizing flax plants with $90 \mathrm{~kg} \mathrm{~N} / \mathrm{ha}$ significantly increased number of branches and capsules/plant and seed yield/ha (Khajani et al,. 2012 ; Homayouni et al., 2013 and Rahimi, 2014). Abdel-Galil et al. (2015) found that the highest mineral nitrogen fertilizer rate $(178.5 \mathrm{~kg} \mathrm{~N} / \mathrm{ha})$ had the highest values of plant height, technical length of the main stem, number of capsules/plant, number of seeds/capsule, $1000-$ seed weight, seed yield per plant and per ha, straw and fiber yields per ha.

Potassium $(\mathrm{K})$ is participate in many important functions in plants i.e. photosynthesis, translocation of photosynthates, protein synthesis, control of ionic balance, regulation of plant stomata and water use (Marschner, 1995 and Reddya et al. 2004), enzyme activation and osmoregulation (Mengel 2007). Also, potassium enhances the ability of plants to resist stress such as diseases, pests, cold and drought. Potassium performs these roles in all crops and flax, therefore it is important plant nutrient to sustain high productivity and quality, in equilibrium with other essential plant nutrients, so it is important to ensure adequate potassium for flax crop. Potassium is usually deficient or unavailable in most Egyptian soils. So, foliar application of this element is the best method of fertilizer application to control its loss from the soil and make it more and easily available to the plant and in turn increase the yield and quality of flax (Arif et al., 2006).

Therefore, this investigation was established to determine the effect of nitrogen fertilizer levels and times of foliar spraying with potassium on straw, fiber and seed yields and its components of some flax genotypes under the environmental conditions of Kafrelshiekh governorate, Egypt. 


\section{MATERIALS AND METHODS}

The present study was carried out at the Experimental Farm, Faculty of Agriculture, Kafrelshiekh University, Egypt, during the two successive winter seasons of 2013/2014 and 2014/2015 to find out the effect of nitrogen fertilizer levels and times of foliar spraying with potassium fertilizer on straw, fiber and seed yields and its components of some flax genotypes.

The experiment was carried out in a split-split plot design with four replications. Where, the main-plots were assigned to flax genotypes as follows:

1. Two genotypes of the dual purpose flax (Sakha 1 and Strain 402/1).

2. Two genotypes of oil flax (Sakha 5 and Strain $541 / G / 1$ ).

3. Two genotypes of fiber flax (Sakha 3 and Strain 620/3/5).

These genotypes were obtained from Fibers Research Section, Field Crops Research Institute, Agricultural Research Center, Giza, Egypt and its pedigree as shown in Table 1.

Table 1: Type and pedigree of studied flax genotypes

\begin{tabular}{|l|l|l|}
\hline Genotype & Type & Pedigree \\
\hline Sakha 1 & Dual purpose & {$[$ Bombay (USA) $\times 1.1485($ USA $)$} \\
\hline Strain 402/1 & Dual purpose & Giza $5 \times$ I. C 235 (USA) \\
\hline Sakha 5 & Oil & I.370 1.2561 \\
\hline Strain 541/C/1 & Oil & Giza $8 \times$ S.24/9/1 \\
\hline Sakha 3 & Fiber & Belinka 2E $\times 1.2096$ \\
\hline Strain 620/3/5 & Fiber & S.422 $\times$ Giza 7 \\
\hline
\end{tabular}

The sub-plots were allocated to nitrogen fertilizer levels (30, 45 and $60 \mathrm{~kg} \mathrm{~N} / \mathrm{fed}$ ). The mineral nitrogen fertilizer in the form of urea $(46.0 \% \mathrm{~N})$ at the mentioned rates was added in two equal doses (the first dose before the first irrigation and the second dose before the second irrigation.

The sub-sub-plots were occupied with the following times of foliar spraying with potassium:

1. Spraying with potassium after 50 days from sowing (DFS).

2. Spraying with potassium after 70 DFS.

3. Spraying with potassium after 50 and 70 DFS.

Foliar spraying was conducted by hand sprayer (for experimental plots) until saturation point at the rate of $200 \mathrm{~L} / \mathrm{fed}$., Potassium fertilizer in the form of commercial compound (Royal potassium) contains $50 \%$ potassium $\left(\mathrm{K}_{2} \mathrm{O}\right)$ at the rate of $1 \mathrm{Liter} / \mathrm{fed}$.

Each experimental unit area was $3 \times 3 \mathrm{~m}$ occupying an area of $9.0 \mathrm{~m}^{2}$. The preceding summer crop was maize (Zea mays L.) in both seasons. Soil samples were taken at random from the experimental field area at a depth of $0-30 \mathrm{~cm}$ from soil surface before the growing 
seasons to measure the physical and chemical soil properties as shown in Table 2.

Table 2: Some physical and chemical properties of the experimental site during 2013/2014 and 2014/2015 seasons

\begin{tabular}{|c|c|c|c|}
\hline \multicolumn{2}{|c|}{ Soil analysis } & $2013 / 2014$ & $2014 / 2015$ \\
\hline \multicolumn{4}{|c|}{ A: Physical analysis } \\
\hline \multicolumn{2}{|l|}{ Clay (\%) } & 40.60 & 42.55 \\
\hline \multicolumn{2}{|l|}{ Silt (\%) } & 32.75 & 35.20 \\
\hline \multicolumn{2}{|l|}{ Sand (\%) } & 21.30 & 24.00 \\
\hline \multicolumn{2}{|l|}{ Texture class } & Clay & Clay \\
\hline \multicolumn{4}{|l|}{ B: Chemical analysis } \\
\hline \multicolumn{2}{|l|}{$\mathrm{pH}$} & 8.05 & 8.12 \\
\hline \multicolumn{2}{|l|}{ E.C. $\left(\mathrm{mho} / \mathrm{cm}\right.$ at $\left.25^{\circ} \mathrm{C}\right)$} & 2.25 & 2.73 \\
\hline \multicolumn{2}{|l|}{ Organic matter (\%) } & 1.45 & 1.25 \\
\hline \multicolumn{2}{|c|}{ Available nitrogen (ppm) } & 25.65 & 20.70 \\
\hline \multicolumn{2}{|l|}{ Available P (ppm) } & 10.17 & 11.45 \\
\hline \multicolumn{2}{|l|}{ Available K (ppm) } & 380.00 & 405.00 \\
\hline \multirow{4}{*}{$\begin{array}{l}\text { Cations (meq./100 g } \\
\text { soil) }\end{array}$} & $\mathrm{Ca}^{++}$ & 5.17 & 7.62 \\
\hline & $\mathrm{Mg}^{++}$ & 4.58 & 2.31 \\
\hline & $\mathrm{Na}^{+}$ & 15.42 & 18.73 \\
\hline & $\mathrm{K}^{+}$ & 0.25 & 0.32 \\
\hline \multirow{3}{*}{$\begin{array}{l}\text { Anions (meq./100 g } \\
\text { soil) }\end{array}$} & $\mathrm{HCO}_{3}{ }^{-}$ & 3.48 & 2.85 \\
\hline & $\mathrm{Cl}^{-}$ & 5.65 & 8.46 \\
\hline & $\mathrm{SO}_{4}$ & 7.35 & 5.24 \\
\hline
\end{tabular}

The experimental field was well prepared through two ploughings, compaction, division and then divided into the experimental units with dimensions as previously mentioned. The mineral phosphorus fertilizer in the form of calcium superphosphate $\left(15.5 \% \mathrm{P}_{2} \mathrm{O}_{5}\right)$ at the rate of $100 \mathrm{~kg} / \mathrm{fed}$. and mineral potassium fertilizer in the form of potassium sulphate $\left(48.0 \% \mathrm{~K}_{2} \mathrm{O}\right)$ at the rate of $50 \mathrm{~kg} / \mathrm{fed}$ were added during seed bed preparation.

Flax genotypes were sown by using broadcasting method at the recommended rate of each genotype on $10^{\text {th }}$ and $17^{\text {th }}$ of November in the first and second seasons, respectively. The other common agricultural practices for growing flax according to the recommendations of Ministry of Agriculture were followed.

\section{STUDIED CHARACTERS:}

Yields and its components:

At full maturity, ten guarded plants were taken at random from each sub-sub plot to be used in recording the following yields and its components.

\section{A. Straw and its components:}

1. Total plant height $(\mathrm{cm})$.

2. Technical length $(\mathrm{cm})$.

3. Stem diameter $(\mathrm{mm})$.

4. Straw yield (g/plant).

5. Straw yield ( $\mathrm{t} / \mathrm{fed})$. It was estimated from the whole sub-sub plot area basis. 
6. Fiber yield (g/plant).

7. Fiber yield $(\mathrm{kg} / \mathrm{fed})$. Long fiber yield/fed were recorded from the whole subplot area basis.

B. Seed and its components:

1. Length of fruiting zone $(\mathrm{cm})$.

2. Number of capsules/plant.

3. Number of seeds/capsule.

4. 1000-seed weight (g).

5. Number of seeds/plant.

6. Seed yield (g/plant).

7. Seed yield $(\mathrm{kg} / \mathrm{fed})$. It was recorded from the whole sub-plot area basis.

All obtained data were statistically analyzed according to the technique of analysis of variance (ANOVA) for the split-split plot design as published by Gomez and Gomez (1984). Means of grains treatments were compared using Duncan's multiple range tests at $5 \%$ level of probability as described by Duncan (1955).

\section{1- GENOTYPES PERFORMANCE:}

\section{RESULT AND DISCUSSION}

From obtained results in Tables 3 and 4, it could be noticed that there were significant differences in straw yield and its components (total plant height, technical length, stem diameter, straw yield "g/plant", straw yield "t/fed", fiber yield "g/plant" and fiber yield "kg/fed") and seed yield and its components (length of fruiting zone, number of capsules/plant, number of seeds/capsule, 1000-seed weight, number of seeds/plant, seed yield "g/plant" and seed yield "kg/fed") among studied flax genotypes i.e. dual purpose flax (Sakha 1 and Strain $402 / 1$ ), oil flax (Sakha 5 and Strain 541/G/1) and fiber flax (Sakha 3 and Strain 620/3/5) in the two growing seasons.

Under conditions of this study, Sakha 1 cultivar produced the highest values of 1000-seed weight of flax at harvesting in both seasons. Meanwhile, Strain 402/1 significantly surpassed other studied genotypes and resulted in the highest values of seed yield ( $\mathrm{g} / \mathrm{plant}$ ) in the second season. However, Sakha 5 produced the highest values of length of fruiting zone, number of capsules/plant, number of seeds/capsule, number of seeds/plant, seed yield per plant (in the first season) and seed yield per feddan of flax at harvesting in both seasons. While, Sakha 3 cultivar resulted in the highest means of total plant height, technical length, straw yield/plant (in the first season) and straw yield/fed in both seasons. Strain 620/3/5 produced the highest values of straw yield/plant (in the second season), fiber yield per plant and per feddan during $2013 / 2014$ and $2014 / 2015$ seasons. It could be concluded that varietal differences among flax genotypes may be due to genetical make up. Similar results were found by Gallardo et al. (2014), Abd Eldaiem (2015 a), Abd Eldaiem (2015 b), Abd ElDayem and El-Borhamy (2015), Barky et al. (2015 a) and ElBorhamy (2016). 


\section{EFFECT OF NITROGEN FERTILIZER LEVELS:}

With respect to the effect of nitrogen fertilizer levels on all studied characters i.e. straw yield and its components (total plant height, technical length, stem diameter, straw yield " $\mathrm{g} / \mathrm{plant}$ ", straw yield "t/fed", fiber yield "g/plant" and fiber yield "kg/fed") and seed yield and its components (length of fruiting zone, number of capsules/plant, number of seeds/capsule, 1000-seed weight, number of seeds/plant, seed yield "g/plant" and seed yield "kg/fed"), it was significant in the two growing seasons of this study (Tables 3 and 4).

All studied characters of flax gradually increased as a result of increasing nitrogen fertilizer levels from 30 to 45 and $60 \mathrm{~kg} \mathrm{~N} / \mathrm{fed}$ in both seasons. It was evident that, under the environmental conditions of this study, flax plants still responded to more levels of nitrogen fertilizer up to $60 \mathrm{~kg} \mathrm{~N} / \mathrm{fed}$. Generally, maximum means of all studied characters were produced from fertilizing flax plants with $60 \mathrm{~kg} \mathrm{~N} / \mathrm{fed}$ in the first and second seasons. On the contrary, the lowest values of these characters were obtained from plots that received lowest nitrogen fertilizer levels $(30 \mathrm{~kg} \mathrm{~N} / \mathrm{fed})$. These increases in straw, fiber and seed yields and its components due to increasing mineral nitrogen fertilizer levels might be due to the role of nitrogen in protoplasm and chlorophyll formation, enhancement meristematic activity and cell division, consequently increases cell size which improving vegetative growth, plant height and stem diameter accordingly increasing straw and fiber yields. Moreover, nitrogen encourages plant to uptake other elements activating, thereby growth of plants, consequently enhancing growth measurements and all seed yield components. Soethe et al. (2013), Rahimi (2014), Abd El-Dayem and El-Borhamy (2015), Abdel-Galil et al. (2015) and El-Borhamy (2016) came out similar results.

\section{EFFECT OF TIMES OF FOLIAR SPRAYING WITH POTASSIUM:}

Times of foliar spraying with potassium (50 DFS, 70 DFS and 50 and 70 DFS) were associated significant effect on straw yield and its components (total plant height, technical length, stem diameter, straw yield " $g /$ plant", straw yield " $t / f e d "$, fiber yield "g/plant" and fiber yield "kg/fed") and seed yield and its components (length of fruiting zone, number of capsules/plant, number of seeds/capsule, 1000-seed weight, number of seeds/plant, seed yield "g/plant" and seed yield "kg/fed") in both seasons (Tables 3 and 4).

Foliar spraying flax plants twice with potassium fertilizer in the form of commercial compound contains $50 \%$ potassium $\left(\mathrm{K}_{2} \mathrm{O}\right)$ at the rate of 1 Liter/fed after 50 and 70 DFS significantly exceeded other studied times of foliar spraying with potassium and produced the highest values of all studied characters in the first and the second 
seasons of this study. This treatment was followed by foliar spraying with potassium one time after 70 DFS concerning all studied characters in the two growing seasons. Whereas, the lowest values of all studied characters were resulted from foliar spraying with potassium one time after 50 DFS in both seasons. The enhancement of straw, fiber and seed yields and its components due to foliar spraying flax plants with potassium may be ascribed to the role of potassium in building up the photosynthetic area of flax plants and consequently increased dry matter accumulation and straw and fiber yields. In addition, providing sufficient potassium for flax often include promoting early plant maturity, resistance to diseases and other pests, vigorous growth, and consequently improved seed yield. A positive association between potassium fertilizer and straw yield has been reported by Bakry et al. (2012 b), Bakry et al. (2015 a) and Barky et al. (2015 b).

\section{4- Effect of interaction:}

With regard to the interactions among the three studied factors, great deals of them were statistically significant in most cases. Thus, the author will discuss only some of them dealing with the second or der of interaction among flax genotype nitrogen fertilizer level and time of foliar spraying with potassium on straw, fiber and seed yields.

The interaction among flax genotype, nitrogen fertilizer level and time of foliar spraying with potassium had a significant effect on straw yield per plant in the first season and straw yield per feddan in the second season. It can be noticed that, the highest value of straw yield per plant in the first season was $(2.750 \mathrm{~g} / \mathrm{plant})$ and straw yield per feddan in the second season was $(4.572 \mathrm{t} / \mathrm{fed})$, which resulted from mineral fertilizing Sakha 3 cultivar with $60 \mathrm{~kg} \mathrm{~N} / \mathrm{fed}$ and foliar spraying twice with potassium at 50 and 70 DFS as presented in Table 5. Mineral fertilizing Sakha 3 cultivar with $60 \mathrm{~kg} \mathrm{~N} / \mathrm{fed}$ and foliar spraying with potassium at 70 DFS considered as the second best interaction treatment regarding to straw yield per plant.

The interaction among flax genotype, nitrogen fertilizer level and time of foliar spraying with potassium had a significant effect on fiber yield per plant in both seasons. It can be observed that, the highest values of fiber yield per plant $(0.810$ and $0.811 \mathrm{~g} /$ plant $)$ ware resulted from mineral fertilizing Strain 620/3/5 with $60 \mathrm{~kg} \mathrm{~N} / \mathrm{fed}$ and foliar spraying twice with potassium at 50 and 70 DFS as presented in Table 6. Mineral fertilizing Strain 620/3/5 with $60 \mathrm{~kg} \mathrm{~N} / \mathrm{fed}$ and foliar spraying with potassium at 70 DFS considered as the second best interaction treatment regarding to fiber yield per plant.

The interaction among flax genotype, nitrogen fertilizer level and time of foliar spraying with potassium had a significant effect on fiber yield per feddan in both seasons. It can be observed that, the 
highest values of fiber yield per feddan $(701.3$ and $689.0 \mathrm{~kg} / \mathrm{fed}$.) were resulted from mineral fertilizing Strain 620/3/5 with $60 \mathrm{~kg} \mathrm{~N} / \mathrm{fed}$ and foliar spraying twice with potassium at 50 and 70 DFS as presented in Table 7. Mineral fertilizing Strain 620/3/5 with $60 \mathrm{~kg} \mathrm{~N} / \mathrm{fed}$ and foliar spraying with potassium at 70 DFS considered as the second best interaction treatment regarding to fiber yield per feddan without significant differences between them in both seasons.

The interaction among flax genotype, nitrogen fertilizer level and times of foliar spraying with potassium had a significant effect on seed yield per plant in both seasons. It can be observed that, the highest values of seed yield per plant $(0.723$ and $0.693 \mathrm{~g} / \mathrm{plant})$ were resulted from mineral fertilizing Sakha 5 with $60 \mathrm{~kg} \mathrm{~N} / \mathrm{fed}$ and foliar spraying twice with potassium at 50 and 70 DFS as presented in Table 8. Mineral fertilizing Sakha 5 with $60 \mathrm{~kg} \mathrm{~N} / \mathrm{fed}$ and foliar spraying with potassium at 70 DFS considered as the second best interaction treatment, followed by mineral fertilizing Sakha 5 with $60 \mathrm{~kg} \mathrm{~N} / \mathrm{fed}$ and foliar spraying with potassium at 50 DFS, then mineral fertilizing Sakha 5 with $45 \mathrm{~kg} \mathrm{~N} / \mathrm{fed}$ and foliar spraying twice with potassium at 50 and 70 DFS and mineral fertilizing Strain 402/1 with $60 \mathrm{~kg} \mathrm{~N} / \mathrm{fed}$ and foliar spraying twice with potassium at 50 and 70 DFS without significant among them in both seasons regarding to seed yield per plant.

The interaction among flax genotype, nitrogen fertilizer level and times of foliar spraying with potassium had a significant effect on seed yield per feddan in both seasons. It can be observed that, the highest values of seed yield per feddan $(779.3$ and $763.2 \mathrm{~kg} / \mathrm{fed})$ were resulted from mineral fertilizing Sakha 5 with $60 \mathrm{~kg} \mathrm{~N} / \mathrm{fed}$. and foliar spraying twice with potassium at 50 and 70 DFS as presented in Table 9. Mineral fertilizing Strain 402/1 with $60 \mathrm{~kg} \mathrm{~N} / \mathrm{fed}$. and foliar spraying with potassium at 50 and 70 DFS considered as the second best interaction treatment regarding to seed yield per feddan in both seasons.

\section{CONCLUSION}

Form the obtained results in this study, it can be concluded that mineral fertilizing Sakha 3 cultivar, Strain 620/3/5 and Sakha 5 with 60 $\mathrm{kg} \mathrm{N} / \mathrm{fed}$ and foliar spraying twice with potassium fertilizer after 50 and 70 DFS from sowing could be recommended in order to maximizing straw, fiber and seed yields, respectively under the some conditions of this research.

\section{REFERENCES}

Abd Eldaiem, M.A.M. (2015 a). Response of some flax genotypes to late sowing. J. Plant Production, Mansoura Univ., 6(7): 275-286.

Abd Eldaiem, M.A.M. (2015 b). Response of some flax genotypes under different plant densities. J. Plant Production, Mansoura Univ., 6(7): 317-328. 
Abd El-Dayem, M.A. and Amal M.A. El-Borhamy (2015). Effect of nitrogen, phosphor and potassium fertilization on yield of flax and quality under sandy soils. J. Plant Production, Mansoura Univ., 6(6):

Abd El-Mohsen, A.A. ; Amany M. Abdallah and Gamalat O. Mahmoud (2013). Optimizing and describing the influence of planting dates and seeding rates on flax cultivars under Middle Egypt region conditions. World Essays J., 1 (4): 142-152.

Abdel-Galil, M.A. ; Sanaa S. Hassan ; Amal M. Elmanzlawy (2015). Influence of three cropping sequences and mineral nitrogen fertilizer rates on flax productivity and profitability under different planting dates in sandy soil. J. of Plant Sci., 3(4): 176-184.

Al-Doori, S.A.M. (2012). Influence of sowing dates on growth, yield and quality of some flax genotypes (Linum usitatissimum L.). College of Basic Education Res. J., 12(1): 733-746.

Arif, M. ; M.A. Khan ; H. Akbar and S. Ali. (2006). Prospects of wheat as a dual purpose crop and its impact on weeds. Pak. J. Weed Sci. Res., 12 (1-2): 13-17.

Bakry, B.A, ; O.A. Nofal and M.S. Zeidan (2012 b). Agronomic characteristics of three flax varieties as affected by some sources of potassium fertilization under newly reclaimed sandy soil conditions. Australian J. of Basic and Appl. Sci., 6(4): 77-81.

Bakry, B.A. ; M.M. Tawfik ; B.B. Mekki and M.S. Zeidan (2012 a). Yield and yield components of three flax cultivars (Linum usitatissimum L.) in response to foliar application with $\mathrm{zn}, \mathrm{mn}$ and fe under newly reclaimed sandy soil conditions. American-Eurasian J. Agric. \& Environ. Sci., 12 (8): 1075-1080.

Bakry, B.A. ; O. Ibrahim ; Elewa T. El-Fattah and M. El-Karamany (2014). Performance assessment of some flax (Linum usitatissimum L.) varieties using cluster analysis under sandy soil conditions. Agric. Sci., 5, 677-686.

Bakry, B.A. ; O.A. Nofal ; M.S. Zeidan and M. Hozayn (2015 a). Potassium and zinc in relation to improve flax varieties yield and yield components as grown under sandy soil conditions. Agric. Sci., 6: 152-158.

Barky, B.A. ; S.I. Shedeed and O.A. Nofal (2015 b). Production and quality traits of two flax varieties as affected by foliar application of silicon fertilizer under sandy soil conditions. Res. J. of Pharmaceutical, Bio. and Chem. Sci., 6(5): 181-188.

Duncan, D.B. (1955). Multiple range and multiple $F$ test. Biometrics, 11: 1-42.

El-Borhamy, Amal, M.A. (2016). Effect of seeding rates and nitrogen fertilizer levels on yield and yield components of two new flax cultivars. J. Agric. Res. Kafr El-Sheikh Univ., J. Plant production, 42(2): 217-229.

Gallardo, M.A. ; H. JoséMilisich ; S.R. Drago and R.J. González (2014). Effect of cultivars and planting date on yield, oil content, and fatty 
acid profile of flax varieties (Linum usitatissimum L.). International J. of Agron., Vol. 2014: 1-7.

Gomez, K.N. and A.A. Gomez (1984). Statistical procedures for agricultural research. John Wiley and Sons, New York, $2^{\text {nd }}$ Ed., 68 P.

Homayouni, G. ; M. Souri and M. Zarein (2013). Effects of zinc and nitrogen on yield components of five flax genotypes. Global J. of Sci. Frontier Res. Chem.. 13 (5): 1-5.

Khajani, F.P. ; H. Irannezhad ; M. Majidian and H. Oraki (2012). Influence of different levels of nitrogen, phosphorus and potassium on yield and yield components of flax seed oil (Linum usitatissimum L.) variety Lirina. J. of Medicinal Plants Res., 6(6): 1050-1054.

Khalifa, R.Kh.M ; F.M. Manal ; A.B. Bakry and M.S. Zeidan (2011). Response of some flax varieties to micronutrients foliar application under newly reclaimed sandy soil. Australian J. of Basic and Applied Sci., 5(8): 1328-1334.

Lafond, G.P. ; C.A. Grant ; A.M. Johnston ; D.W. McAndrew and W.E. May (2003). Nitrogen and phosphorus fertilizer management of notill flax. Better Crops, 87(1): 6-11.

Marschner, H. (1995). Mineral nutrition of higher plants. Academic press San Diego, USA.

Mengel, K. (2007). Potassium. In "Handbook of Plant Nutrition" (Eds. Barker AV, Pilbeam DJ) 1st ed. pp: 91-120.

Mousa, M. A. ; Eman A.E. El-Kady and Z.S. Zedan (2010). Effect of nitrogen fertilizers and some micronutrients on flax yield and chemical composition characters. J. Plant Production, Mansoura Univ., 1(5): 713-720.

Rahimi, M.M. (2014). Effect of sowing date and nitrogen on yield and yield components of medicinal flax. Intern. J. of Biosci., 5(12): 160165.

Rahimi, M.M. and G. Nourmohamadi (2010). The effect of different planting dates on yield of different medicinal flax cultivars. J. of New Agric. Sci. (Modern Sci. of Sust. Agric.), 6(19): 31-39.

Reddya, A.R. ; K.V. Chaitanya and M. Vivekanandanb (2004). Droughtinduced responses of photosynthesis and antioxidant metabolism in higher plants. J. Plant Physiol., 161: 1189-1202.

Soethe, G. ; A. Feiden ; D. Bassegio ; R.F. Santos ; S.N.M. Souza and D. Secco (2013). Sources and rates of nitrogen in the cultivation of flax. African J. of Agric. Res., 8(19): 2249-2253.

Wadan, A. (2013). Optimizing and describing the influence of planting dates and seeding rates on flax cultivars under Middle Egypt region conditions. J. of Sci. Res. and Rev., 1(2): 28-39. 
Table 3: Total plant height $(\mathrm{cm})$, technical length $(\mathrm{cm})$, stem diameter $(\mathrm{mm})$, straw and fiber yields per plant $(\mathrm{g})$ and per feddan $(\mathrm{kg})$ of of some flax genotypes as affected by nitrogen fertilizer level and times of foliar spraying with potassium during 2013/2014 and 2014/2015 seasons

\begin{tabular}{|c|c|c|c|c|c|c|c|c|c|c|c|c|c|c|c|c|c|c|c|c|c|c|c|c|c|c|c|c|}
\hline \multirow{2}{*}{$\begin{array}{l}\text { Treatment } \\
\text { A. Genotype }\end{array}$} & \multicolumn{4}{|c|}{ Total plant height (cm) } & \multicolumn{4}{|c|}{ Technical length $(\mathrm{cm})$} & \multicolumn{4}{|c|}{ Stem diameter $(\mathrm{mm})$} & \multicolumn{4}{|c|}{$\begin{array}{c}\text { Straw yield } \\
\text { (g/plant) }\end{array}$} & \multicolumn{4}{|c|}{$\begin{array}{l}\text { Straw yield } \\
\text { (thed.) }\end{array}$} & \multicolumn{4}{|c|}{$\begin{array}{l}\begin{array}{l}\text { Fiber yield } \\
\text { (g/plant) }\end{array} \\
\text { (a) }\end{array}$} & \multicolumn{4}{|c|}{$\begin{array}{l}\text { Fiber yield } \\
\text { (kgyted.) }\end{array}$} \\
\hline & \multicolumn{2}{|c|}{$2013 / 2014$} & \multicolumn{2}{|c|}{$2014 / 2015$} & \multicolumn{2}{|c|}{$2013 / 2014$} & \multicolumn{2}{|c|}{$2014 / 2015$} & \multicolumn{2}{|c|}{$2013 / 2014$} & \multicolumn{2}{|c|}{ 2014/2015 } & \multicolumn{2}{|c|}{$2013 / 2014$} & \multicolumn{2}{|c|}{$2014 / 2015$} & \multicolumn{2}{|c|}{$2013 / 2014$} & \multicolumn{2}{|c|}{$2014 / 2015$} & \multicolumn{2}{|c|}{ 2013/2014 } & \multicolumn{2}{|c|}{$2014 / 2015$} & \multicolumn{2}{|c|}{$2013 / 2014$} & \multicolumn{2}{|c|}{$2014 / 2015$} \\
\hline Sakha 1 & 96. & b & $\begin{array}{ll}104 \\
41\end{array}$ & $a b$ & 86. & bc & 90.28 & b & 1.964 & a & 1.7 & a & 1.695 & b & $\begin{array}{l}1.5 \\
94\end{array}$ & ab & 3.840 & $\mathrm{~b}$ & $\begin{array}{l}3.8 \\
74\end{array}$ & $\mathrm{~b}$ & 0.594 & $\mathrm{~b}$ & 0.60 & bc & 584.2 & c & 614.6 & a \\
\hline Strain 402/1 & 100 & ab & 99. & b & 87. & c & 88.65 & c & 1.747 & b & 1.7 & $a b$ & 1.729 & $\mathrm{~b}$ & 1.6 & ab & 3.862 & b & 3.9 & ab & 0.632 & a & $\frac{0.57}{3}$ & cd & 566.1 & d & 619.0 & $\mathrm{a}$ \\
\hline Sakha 5 & $\begin{array}{l}78 . \\
44 .\end{array}$ & d & $\begin{array}{l}74 . \\
53\end{array}$ & c & $\frac{62 .}{7}$ & e & 60.9 & d & 1.606 & $\mathrm{~b}$ & $\begin{array}{l}7.5 \\
42 \\
42\end{array}$ & $\mathrm{c}$ & 1.389 & c & $\begin{array}{l}1.3 \\
76\end{array}$ & c & 3.541 & c & $\begin{array}{l}3.5 \\
16\end{array}$ & c & 0.467 & $\mathrm{c}$ & $\begin{array}{c}0.51 \\
1\end{array}$ & e & 452.5 & 1 & 464.5 & $\mathrm{c}$ \\
\hline Strain $541 / 6 / 1$ & $\begin{array}{l}94 . \\
10\end{array}$ & c & $\begin{array}{l}93 . \\
99\end{array}$ & b & $\frac{82 .}{7}$ & d & 82.7 & c & 1.669 & b & $\begin{array}{l}1.6 \\
82\end{array}$ & $\mathrm{~b}$ & 1.500 & c & $\begin{array}{l}1.5 \\
09\end{array}$ & bc & 3.496 & c & $\begin{array}{l}3.4 \\
79\end{array}$ & c & 0.486 & c & $\begin{array}{c}0.52 \\
9\end{array}$ & de & 473.5 & e & 485.1 & b \\
\hline Sakha 3 & $\begin{array}{l}122 \\
.70\end{array}$ & $\mathrm{a}$ & $\begin{array}{l}1.70 \\
.70 \\
\end{array}$ & $a$ & $\begin{array}{l}102 \\
.5 \\
\end{array}$ & $\mathrm{a}$ & 113.2 & a & 1.711 & $\mathrm{~b}$ & $\begin{array}{l}1.6 \\
43 \\
\end{array}$ & $\mathrm{~b}$ & 1.980 & $\mathrm{a}$ & $\begin{array}{l}1.6 \\
15 \\
15\end{array}$ & ab & 4.044 & $\mathrm{a}$ & $\begin{array}{l}4.1 \\
11\end{array}$ & $\mathrm{a}$ & 0.649 & $\mathrm{a}$ & $\begin{array}{l}0.63 \\
6\end{array}$ & ab & 605.2 & $\mathrm{~b}$ & 615.5 & $\mathrm{a}$ \\
\hline Strain 620/3/5 & $\begin{array}{l}105 \\
.60\end{array}$ & $a b$ & ${ }_{83}^{98 .}$ & b & $\begin{array}{l}94 . \\
85\end{array}$ & $\mathrm{~b}$ & 94.58 & $\mathrm{~b}$ & 1.692 & $\mathrm{~b}$ & $\begin{array}{l}1.7 \\
17\end{array}$ & $a b$ & 1.961 & $a$ & $\begin{array}{l}1.7 \\
15\end{array}$ & a & 3.898 & $\mathrm{~b}$ & $\begin{array}{l}4.0 \\
72\end{array}$ & $\mathrm{a}$ & 0.657 & $a$ & $\begin{array}{l}0.66 \\
3\end{array}$ & $\mathrm{a}$ & 627.5 & a & 619.5 & $a$ \\
\hline \multicolumn{29}{|c|}{$\begin{array}{l}\text { F. test } \\
B-\text { Nitrogen fertilizer level: }\end{array}$} \\
\hline $30 \mathrm{~kg} \mathrm{~N}$ tied & $\begin{array}{l}85 . \\
00\end{array}$ & $\mathrm{c}$ & $\begin{array}{l}84 . \\
54\end{array}$ & c & $\begin{array}{l}75.5 \\
05\end{array}$ & $\mathrm{c}$ & $\begin{array}{ll}74.31 \\
\end{array}$ & c & 1.449 & c & $\begin{array}{l}.3 \\
98\end{array}$ & $\mathrm{c}$ & 1.293 & c & $\begin{array}{l}1.1 \\
38\end{array}$ & c & 3.443 & c & $\begin{array}{l}3.5 \\
19 \\
\end{array}$ & c & 0.452 & $\mathrm{~b}$ & $\begin{array}{l}0.46 \\
8\end{array}$ & c & $\begin{array}{l}503.1 \\
\end{array}$ & c & 517.5 & c \\
\hline $45 \mathrm{~kg}$ Nhed & $\begin{array}{l}99.9 \\
00\end{array}$ & b & $\begin{array}{l}101 \\
{ }_{49}\end{array}$ & $\mathrm{~b}$ & $\begin{array}{l}86 . \\
855\end{array}$ & b & \begin{tabular}{|l|l|}
90.98 \\
\end{tabular} & $\mathrm{~b}$ & 1.755 & b & $\begin{array}{l}1.7 \\
41\end{array}$ & b & 1.778 & $\mathrm{~b}$ & $\begin{array}{l}1.6 \\
67\end{array}$ & b & 3.874 & b & $\begin{array}{l}3.9 \\
42\end{array}$ & $\mathrm{~b}$ & 0.638 & a & $\begin{array}{l}0.63 \\
7\end{array}$ & $\mathrm{~b}$ & 564.1 & $\mathrm{~b}$ & 573.4 & $\mathrm{~b}$ \\
\hline $60 \mathrm{~kg}$ N/ed & $\begin{array}{l}109 \\
30\end{array}$ & a & $\begin{array}{l}109 \\
79\end{array}$ & a & $\begin{array}{l}966 . \\
35\end{array}$ & $\mathbf{a}$ & \begin{tabular}{|l|l|}
99.90 \\
\end{tabular} & a & 1.990 & a & $\begin{array}{l}1.9 \\
01\end{array}$ & a & 2.056 & a & $\begin{array}{l}1.9 \\
17\end{array}$ & a & 4.024 & a & $\begin{array}{l}4.0 \\
53\end{array}$ & a & 0.652 & $\mathrm{a}$ & $\begin{array}{l}0.65 \\
4\end{array}$ & a & 587.3 & a & 618.3 & $a$ \\
\hline \multicolumn{29}{|c|}{\begin{tabular}{l|l} 
F.test \\
C. Times of follar sp
\end{tabular}} \\
\hline 50 & $\begin{array}{l}93 . \\
60\end{array}$ & $\mathrm{c}$ & $\begin{array}{l}96 . \\
96 .\end{array}$ & $\mathrm{c}$ & $\begin{array}{l}83 . \\
035 . \\
0.5\end{array}$ & c & 86.38 & c & 1.601 & c & $\begin{array}{l}1.5 \\
27 \\
27\end{array}$ & c & 1.497 & c & $\begin{array}{l}1.3 \\
40\end{array}$ & c & 3.580 & c & $\begin{array}{l}3.6 \\
92\end{array}$ & c & 0.549 & b & 0.54 & c & 536.0 & c & 551.6 & c \\
\hline 70 & $\begin{array}{l}98 . \\
40.9\end{array}$ & b & $\begin{array}{l}98 . \\
77\end{array}$ & b & $\begin{array}{l}886 . \\
55\end{array}$ & b & 88.28 & b & 1.706 & $\mathrm{~b}$ & $\begin{array}{l}1.6 \\
70\end{array}$ & b & 1.690 & $\mathrm{~b}$ & $\begin{array}{l}1.6 \\
04\end{array}$ & b & 3.811 & b & $\begin{array}{l}3.8 \\
55\end{array}$ & $\mathrm{~b}$ & 0.561 & $\mathrm{~b}$ & $\frac{0.59}{1}$ & $\mathrm{~b}$ & 551.5 & $\mathrm{~b}$ & 571.0 & $\mathrm{~b}$ \\
\hline 50 and 70 & $\begin{array}{l}101 \\
30\end{array}$ & a & $\begin{array}{l}100 \\
68\end{array}$ & a & $\begin{array}{l}88 . \\
65 .\end{array}$ & a & $\begin{array}{l}90.53 \\
\end{array}$ & a & 1.887 & a & $\begin{array}{l}1.8 \\
43\end{array}$ & a & 1.939 & $a$ & $\begin{array}{l}1.7 \\
79\end{array}$ & a & 3.949 & a & $\begin{array}{l}3.9 \\
68\end{array}$ & 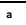 & 0.632 & $a$ & $\begin{array}{l}0.62 \\
7\end{array}$ & $a$ & 567.1 & $a$ & 586.5 & $a$ \\
\hline \multicolumn{29}{|l|}{$\begin{array}{l}\text { F. test } \\
D \text {-Interactions } \\
\end{array}$} \\
\hline$\frac{D \text { minet }}{A} \times B$ & & & & & & & & & N & & & & & & & & & & & & 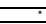 & & 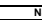 & & & & & \\
\hline$A \times C$ & & & & & & & & & Ns & & & & NS & & & & NS & & & & & & & & & & & \\
\hline$\frac{B \times C}{A \times B \times C}$ & & & & & & & & & $\bar{N}$ & & & & & & & & NS & & & & & & & & & & & \\
\hline
\end{tabular}

*** and NS indicate $\mathrm{P}<0.05, \mathrm{P}<0.01$ and not significant, respectively.

Means followed by the same letter within columns are not significantly different at $P<0.05$ using Duncan`s multiple range test. 
Table 4: Length of fruiting zone $(\mathrm{cm})$, number of capsules/plant, number of seeds/capsule, 1000-seed weight $(\mathrm{g})$, number of seeds/plant, seed yield per plant $(\mathrm{g})$ and per feddan $(\mathrm{kg})$ of some flax genotypes as affected by nitrogen fertilizer level and times of foliar spraying with potassium during $2013 / 2014$ and $2014 / 2015$ seasons

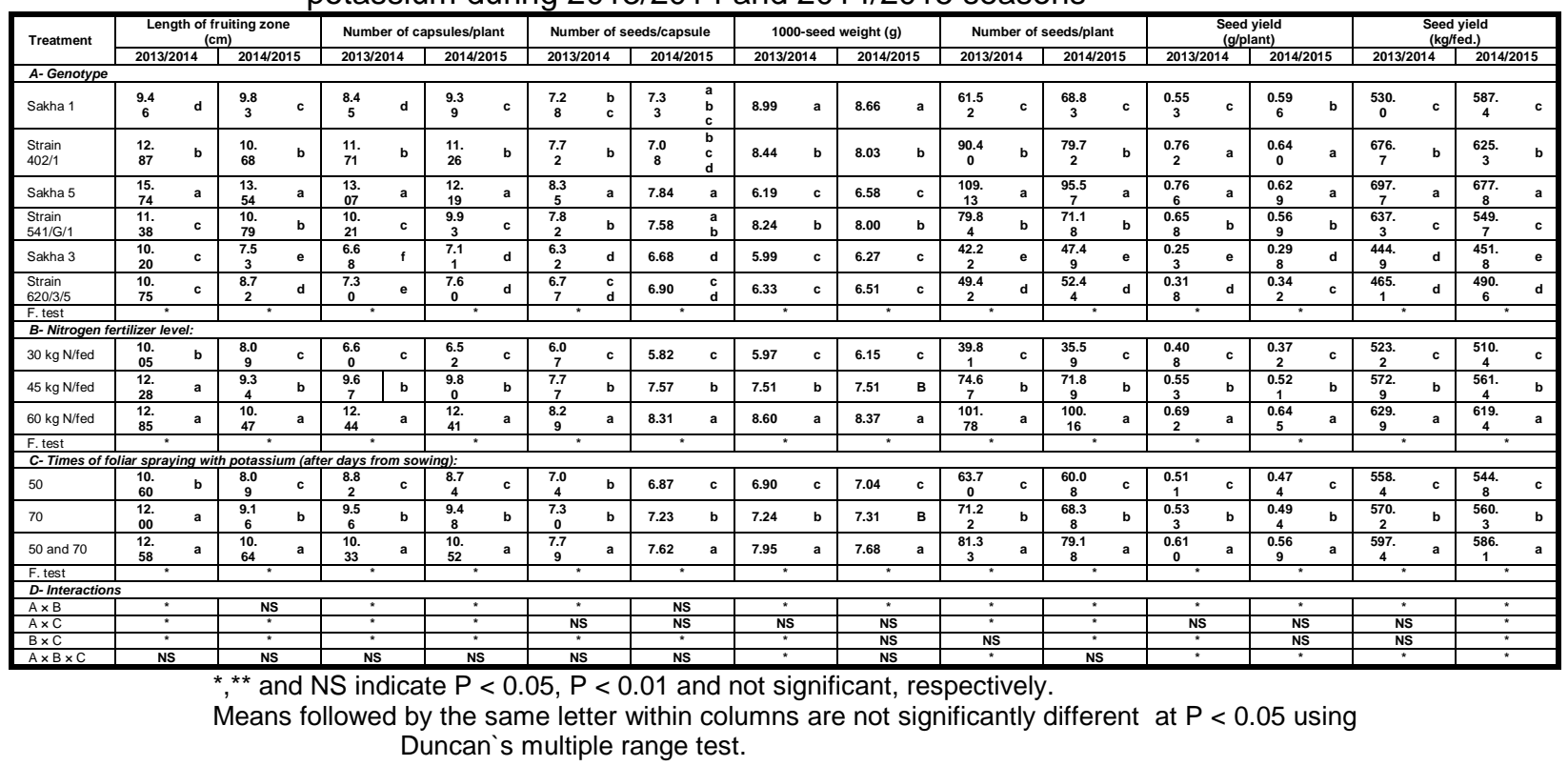


Table 5: Straw yield of flax per plant during 2013/2014 season and per feddan during 2014/2015 season as affected by the interaction among genotype, nitrogen fertilizer level and time of foliar spraying with potassium

\begin{tabular}{|c|c|c|c|c|c|c|}
\hline \multirow{2}{*}{\multicolumn{2}{|c|}{ Treatment }} & & \multirow{2}{*}{\multicolumn{2}{|c|}{$\begin{array}{c}\begin{array}{c}\text { Straw yield } \\
\text { (g/plant) }\end{array} \\
2013 / 2014\end{array}$}} & \multicolumn{2}{|c|}{$\begin{array}{l}\text { Straw yield } \\
\text { (t/fed.) }\end{array}$} \\
\hline & & & 201 & & 201 & 2015 \\
\hline \multirow{9}{*}{ Sakha 1} & \multirow{3}{*}{$30 \mathrm{~kg} \mathrm{~N} / \mathrm{fed}$} & 50 DFS & 0.750 & uvw & 3.363 & opqrs \\
\hline & & 70 DFS & 0.997 & stuvw & 3.188 & qrs \\
\hline & & $50 \& 70$ DFS & 0.893 & tuvw & 3.439 & mnopqrs \\
\hline & \multirow{3}{*}{$45 \mathrm{~kg} \mathrm{~N} / \mathrm{fed}$} & 50 DFS & 1.237 & pqrstuv & 3.548 & klmnopqr \\
\hline & & 70 DFS & 1.703 & ghijklmnopq & 4.025 & abcdefghijkl \\
\hline & & $50 \& 70$ DFS & 1.473 & klmnopqrs & 4.262 & abcdefg \\
\hline & \multirow{3}{*}{$60 \mathrm{~kg} \mathrm{~N} / \mathrm{fed}$} & 50 DFS & 1.727 & ghijklmnop & 4.475 & abcd \\
\hline & & 70 DFS & 1.933 & defghijklm & 4.043 & abcdefghijkl \\
\hline & & $50 \& 70$ DFS & 1.783 & efghijklmnop & 4.525 & $a b c$ \\
\hline \multirow{9}{*}{$\begin{array}{l}\text { Strain } \\
402 / 1\end{array}$} & \multirow{3}{*}{$30 \mathrm{~kg} \mathrm{~N} / \mathrm{fed}$} & 50 DFS & 1.383 & mnopqrst & 3.588 & jklmnopqr \\
\hline & & 70 DFS & 1.007 & stuvw & 3.987 & bcdefghijklm \\
\hline & & $50 \& 70$ DFS & 1.380 & nopqrst & 4.044 & abcdefghijkl \\
\hline & \multirow{3}{*}{$45 \mathrm{~kg} \mathrm{~N} / \mathrm{fed}$} & 50 DFS & 1.700 & ghijklmnopq & 3.871 & fghijklmnop \\
\hline & & 70 DFS & 1.800 & efghijklmn & 4.312 & abcdef \\
\hline & & $50 \& 70$ DFS & 1.783 & efghijklmnop & 3.972 & cdefghijklm \\
\hline & \multirow{3}{*}{$60 \mathrm{~kg} \mathrm{~N} / \mathrm{fed}$} & 50 DFS & 2.133 & cdefghi & 4.087 & abcdefghijkl \\
\hline & & 70 DFS & 1.750 & fghijklmnop & 4.453 & abcde \\
\hline & & $50 \& 70$ DFS & 2.317 & abcde & 4.330 & abcdef \\
\hline \multirow{9}{*}{ Sakha 5} & \multirow{3}{*}{$30 \mathrm{~kg} \mathrm{~N} / \mathrm{fed}$} & 50 DFS & 0.717 & vw & 3.240 & qrs \\
\hline & & 70 DFS & 1.003 & stuvw & 3.261 & qrs \\
\hline & & $50 \& 70$ DFS & 1.467 & klmnopqrs & 3.305 & pqrs \\
\hline & \multirow{3}{*}{$45 \mathrm{~kg} \mathrm{~N} / \mathrm{fed}$} & 50 DFS & 1.617 & ijklmnopqr & 3.686 & hijklmnopqr \\
\hline & & 70 DFS & 0.567 & $w$ & 3.686 & hijklmnopqr \\
\hline & & $50 \& 70$ DFS & 2.107 & cdefghi & 3.629 & ijklmnopqr \\
\hline & \multirow{3}{*}{$60 \mathrm{~kg} \mathrm{~N} / \mathrm{fed}$} & 50 DFS & 1.793 & efghijklmno & 3.122 & rs \\
\hline & & 70 DFS & 2.067 & defghij & 3.976 & cdefghijklm \\
\hline & & $50 \& 70$ DFS & 2.163 & cdefghi & 3.742 & ghijklmnopq \\
\hline \multirow{9}{*}{$\begin{array}{l}\text { Strain } \\
541 / G / 1\end{array}$} & \multirow{3}{*}{$30 \mathrm{~kg} \mathrm{~N} / \mathrm{fed}$} & 50 DFS & 0.893 & tuvw & 3.208 & qrs \\
\hline & & 70 DFS & 1.663 & hijklmnopqr & 3.387 & nopqrs \\
\hline & & $50 \& 70$ DFS & 1.917 & defghijklmn & 3.348 & opqrs \\
\hline & \multirow{3}{*}{$45 \mathrm{~kg} \mathrm{~N} / \mathrm{fed}$} & 50 DFS & 1.250 & opqrstu & 3.736 & ghijklmnopq \\
\hline & & 70 DFS & 1.847 & efghijklmn & 2.968 & $\mathrm{~s}$ \\
\hline & & $50 \& 70$ DFS & 2.150 & cdefghi & 3.724 & ghijklmnopq \\
\hline & & 50 DFS & 1.633 & ijklmnopqr & 3.732 & ghijklmnopq \\
\hline & $60 \mathrm{~kg} \mathrm{~N} / \mathrm{fed}$ & 70 DFS & 2.207 & bcdefgh & 3.528 & Imnopqr \\
\hline & & $50 \& 70$ DFS & 2.000 & defghijk & 3.681 & hijklmnopqr \\
\hline & & 50 DFS & 1.417 & Imnopqrst & 3.557 & klmnopqr \\
\hline & $30 \mathrm{~kg} \mathrm{~N} / \mathrm{fed}$ & 70 DFS & 1.887 & efghijklmn & 3.901 & efghijklmno \\
\hline & & $50 \& 70$ DFS & 1.843 & efghijklmn & 4.198 & abcdefghi \\
\hline & & 50 DFS & 1.530 & jklmnopqrs & 4.046 & abcdefghijkl \\
\hline Sakha 3 & $45 \mathrm{~kg} \mathrm{~N} / \mathrm{fed}$ & 70 DFS & 1.987 & defghijk & 4.354 & abcdef \\
\hline & & $50 \& 70$ DFS & 2.280 & abcdef & 4.123 & abcdefghijk \\
\hline & & 50 DFS & 1.417 & Imnopqrst & 4.143 & abcdefghij \\
\hline & $60 \mathrm{~kg} \mathrm{~N} / \mathrm{fed}$ & 70 DFS & 2.707 & $a b$ & 4.120 & abcdefghijk \\
\hline & & $50 \& 70$ DFS & 2.750 & $a$ & 4.572 & $a$ \\
\hline & & 50 DFS & 1.163 & qrstuv & 3.234 & qrs \\
\hline & $30 \mathrm{~kg} \mathrm{~N} / \mathrm{fed}$ & 70 DFS & 1.157 & rstuv & 3.382 & nopqrs \\
\hline & & $50 \& 70$ DFS & 1.737 & fghijklmnop & 3.714 & ghijklmnopq \\
\hline & & 50 DFS & 2.140 & cdefghi & 3.862 & fghijklmnop \\
\hline Strain & $45 \mathrm{~kg} \mathrm{~N} / \mathrm{fed}$ & 70 DFS & 2.203 & bcdefgh & 4.247 & abcdefgh \\
\hline $620 / 3 / 5$ & & $50 \& 70$ DFS & 2.623 & $a b c$ & 4.476 & abcd \\
\hline & & 50 DFS & 2.450 & abcd & 3.951 & defghijklmn \\
\hline & $60 \mathrm{~kg} \mathrm{~N} / \mathrm{fed}$ & 70 DFS & 1.943 & defghijkl & 4.350 & abcdef \\
\hline & & $50 \& 70$ DFS & 2.233 & bcdefg & 4.556 & $a b$ \\
\hline
\end{tabular}

Means followed by the same letter within columns are not significantly different at $P<0.05$ using Duncan`s multiple range test. 
Table 6: Fiber yield per plant of flax at as affected by the interaction among genotype, nitrogen fertilizer level and time of foliar spraying with potassium during 2013/2014 and 2014/2015 seasons

\begin{tabular}{|c|c|c|c|c|c|c|}
\hline \multirow{2}{*}{\multicolumn{2}{|c|}{ Treatment }} & & \multicolumn{4}{|c|}{ Fiber yield (g/plant) } \\
\hline & & & \multicolumn{2}{|c|}{$2013 / 2014$} & \multicolumn{2}{|c|}{$2014 / 2015$} \\
\hline \multirow{9}{*}{ Sakha 1} & \multirow{3}{*}{$30 \mathrm{~kg} \mathrm{~N} / \mathrm{fed}$} & 50 DFS & 0.437 & mnopqrs & 0.387 & $\mathrm{n}$ \\
\hline & & 70 DFS & 0.393 & pqrs & 0.470 & jklmn \\
\hline & & $50 \& 70$ DFS & 0.503 & jklmnopq & 0.603 & fghi \\
\hline & \multirow{3}{*}{$45 \mathrm{~kg} \mathrm{~N} / \mathrm{fed}$} & 50 DFS & 0.603 & efghijk & 0.657 & cdefgh \\
\hline & & 70 DFS & 0.643 & bcdefghi & 0.567 & hij \\
\hline & & $50 \& 70$ DFS & 0.730 & abcd & 0.643 & defgh \\
\hline & \multirow{3}{*}{$60 \mathrm{~kg} \mathrm{~N} / \mathrm{fed}$} & 50 DFS & 0.657 & bcdefghi & 0.700 & bcdefg \\
\hline & & 70 DFS & 0.673 & bcdefgh & 0.703 & bcdef \\
\hline & & $50 \& 70$ DFS & 0.707 & abcde & 0.727 & abcd \\
\hline \multirow{9}{*}{$\begin{array}{l}\text { Strain } \\
402 / 1\end{array}$} & \multirow{3}{*}{$30 \mathrm{~kg} \mathrm{~N} / \mathrm{fed}$} & 50 DFS & 0.457 & Imnopqrs & 0.400 & $\mathrm{n}$ \\
\hline & & 70 DFS & 0.450 & Imnopqrs & 0.440 & $\mathrm{mn}$ \\
\hline & & $50 \& 70$ DFS & 0.550 & hijklmn & 0.573 & hij \\
\hline & \multirow{3}{*}{$45 \mathrm{~kg} \mathrm{~N} / \mathrm{fed}$} & 50 DFS & 0.770 & $a b$ & 0.653 & cdefgh \\
\hline & & 70 DFS & 0.720 & abcde & 0.623 & defgh \\
\hline & & $50 \& 70$ DFS & 0.710 & abcde & 0.703 & bcdef \\
\hline & \multirow{3}{*}{$60 \mathrm{~kg} \mathrm{~N} / \mathrm{fed}$} & 50 DFS & 0.697 & abcdef & 0.580 & hi \\
\hline & & 70 DFS & 0.640 & cdefghi & 0.630 & defgh \\
\hline & & $50 \& 70$ DFS & 0.693 & abcdef & 0.557 & hijkl \\
\hline \multirow{9}{*}{ Sakha 5} & \multirow{3}{*}{$30 \mathrm{~kg} \mathrm{~N} / \mathrm{fed}$} & 50 DFS & 0.360 & rs & 0.397 & $\mathrm{n}$ \\
\hline & & 70 DFS & 0.347 & $\mathrm{~s}$ & 0.413 & $\mathrm{mn}$ \\
\hline & & $50 \& 70$ DFS & 0.507 & jklmnop & 0.473 & jklmn \\
\hline & \multirow{3}{*}{$45 \mathrm{~kg} \mathrm{~N} / \mathrm{fed}$} & 50 DFS & 0.483 & klmnopqr & 0.510 & ijklm \\
\hline & & 70 DFS & 0.417 & opqrs & 0.610 & efghi \\
\hline & & $50 \& 70$ DFS & 0.493 & jklmnopq & 0.593 & ghi \\
\hline & \multirow{3}{*}{$60 \mathrm{~kg} \mathrm{~N} / \mathrm{fed}$} & 50 DFS & 0.447 & mnopqrs & 0.563 & hijk \\
\hline & & 70 DFS & 0.603 & efghijk & 0.587 & hi \\
\hline & & $50 \& 70$ DFS & 0.550 & hijklmn & 0.613 & efghi \\
\hline \multirow{9}{*}{$\begin{array}{l}\text { Strain } \\
541 / G / 1\end{array}$} & \multirow{3}{*}{$30 \mathrm{~kg} \mathrm{~N} / \mathrm{fed}$} & 50 DFS & 0.353 & $\mathrm{~s}$ & 0.383 & $\mathrm{n}$ \\
\hline & & 70 DFS & 0.390 & pqrs & 0.413 & $\mathrm{mn}$ \\
\hline & & $50 \& 70$ DFS & 0.433 & nopqrs & 0.433 & $\mathrm{mn}$ \\
\hline & & 50 DFS & 0.403 & pqrs & 0.460 & klmn \\
\hline & $45 \mathrm{~kg} \mathrm{~N} / \mathrm{fed}$ & 70 DFS & 0.407 & pqrs & 0.557 & hijkl \\
\hline & & $50 \& 70$ DFS & 0.660 & bcdefghi & 0.603 & fghi \\
\hline & & 50 DFS & 0.573 & fghijkl & 0.457 & Imn \\
\hline & $60 \mathrm{~kg} \mathrm{~N} / \mathrm{fed}$ & 70 DFS & 0.537 & ijklmno & 0.653 & cdefgh \\
\hline & & $50 \& 70$ DFS & 0.613 & defghij & 0.640 & defgh \\
\hline & & 50 DFS & 0.470 & Imnopqrs & 0.447 & $\mathrm{mn}$ \\
\hline & $30 \mathrm{~kg} \mathrm{~N} / \mathrm{fed}$ & 70 DFS & 0.483 & klmnopqr & 0.457 & Imn \\
\hline & & $50 \& 70$ DFS & 0.600 & efghijk & 0.570 & hij \\
\hline & & 50 DFS & 0.683 & bcdefg & 0.607 & efghi \\
\hline Sakha 3 & $45 \mathrm{~kg} \mathrm{~N} / \mathrm{fed}$ & 70 DFS & 0.680 & bcdefg & 0.757 & $a b c$ \\
\hline & & $50 \& 70$ DFS & 0.763 & $a b c$ & 0.753 & $a b c$ \\
\hline & & 50 DFS & 0.630 & defghi & 0.700 & bcdefg \\
\hline & $60 \mathrm{~kg} \mathrm{~N} / \mathrm{fed}$ & 70 DFS & 0.763 & $a b c$ & 0.727 & abcd \\
\hline & & $50 \& 70$ DFS & 0.760 & $a b c$ & 0.710 & abcdef \\
\hline & & 50 DFS & 0.380 & qrs & 0.433 & $\mathrm{mn}$ \\
\hline & $30 \mathrm{~kg} \mathrm{~N} / \mathrm{fed}$ & 70 DFS & 0.463 & Imnopqrs & 0.553 & hijkl \\
\hline & & $50 \& 70$ DFS & 0.560 & ghijklm & 0.583 & hi \\
\hline & & 50 DFS & 0.757 & $a b c$ & 0.703 & bcdef \\
\hline Strain & $45 \mathrm{~kg} \mathrm{~N} / \mathrm{fed}$ & 70 DFS & 0.730 & abcd & 0.660 & cdefgh \\
\hline $620 / 3 / 5$ & & $50 \& 70$ DFS & 0.770 & $a b$ & 0.713 & abcde \\
\hline & & 50 DFS & 0.677 & bcdefg & 0.710 & abcdef \\
\hline & $60 \mathrm{~kg} \mathrm{~N} / \mathrm{fed}$ & 70 DFS & 0.770 & $a b$ & 0.800 & $a b$ \\
\hline & & $50 \& 70$ DFS & 0.810 & $\mathrm{a}$ & 0.811 & $a$ \\
\hline
\end{tabular}

Means followed by the same letter within columns are not significantly different at $P<0.05$ using Duncan`s multiple range test. 
Table 7: Fiber yield per feddan of flax as affected by the interaction among genotype, nitrogen fertilizer level and time of foliar spraying with potassium during 2013/2014 and 2014/2015 seasons

\begin{tabular}{|c|c|c|c|c|c|c|}
\hline \multirow{2}{*}{\multicolumn{2}{|c|}{ Treatment }} & & \multicolumn{4}{|c|}{ Fiber yield (kg/fed.) } \\
\hline & & & \multicolumn{2}{|c|}{$2013 / 2014$} & \multicolumn{2}{|c|}{$2014 / 2015$} \\
\hline \multirow{9}{*}{ Sakha 1} & \multirow{3}{*}{$30 \mathrm{~kg} \mathrm{~N} / \mathrm{fed}$} & 50 DFS & 524.7 & mnop & 514.7 & nopq \\
\hline & & 70 DFS & 596.8 & defghij & 583.5 & $\mathrm{ijkl}$ \\
\hline & & $50 \& 70$ DFS & 592.7 & efghijk & 607.0 & ghij \\
\hline & \multirow{3}{*}{$45 \mathrm{~kg} \mathrm{~N} / \mathrm{fed}$} & 50 DFS & 563.6 & hijklmno & 620.5 & defghij \\
\hline & & 70 DFS & 616.7 & bcdefgh & 611.1 & fghij \\
\hline & & $50 \& 70$ DFS & 585.8 & fghijklm & 650.4 & abcdef \\
\hline & \multirow{3}{*}{$60 \mathrm{~kg} \mathrm{~N} / \mathrm{fed}$} & 50 DFS & 596.1 & defghij & 618.0 & efghij \\
\hline & & 70 DFS & 598.0 & cdefghij & 661.1 & abcd \\
\hline & & $50 \& 70$ DFS & 583.6 & fghijklm & 664.9 & $a b c$ \\
\hline \multirow{9}{*}{$\begin{array}{l}\text { Strain } \\
402 / 1\end{array}$} & \multirow{3}{*}{$30 \mathrm{~kg} \mathrm{~N} / \mathrm{fed}$} & 50 DFS & 541.3 & jklmnop & 541.5 & $\mathrm{mno}$ \\
\hline & & 70 DFS & 508.6 & opq & 579.5 & $\mathrm{jk} / \mathrm{m}$ \\
\hline & & $50 \& 70$ DFS & 502.0 & opq & 593.9 & hij \\
\hline & \multirow{3}{*}{$45 \mathrm{~kg} \mathrm{~N} / \mathrm{fed}$} & 50 DFS & 573.9 & ghijklmn & 604.3 & hij \\
\hline & & 70 DFS & 547.7 & ijklmnop & 603.2 & hij \\
\hline & & $50 \& 70$ DFS & 588.9 & fghijkl & 646.9 & abcdefg \\
\hline & \multirow{3}{*}{$60 \mathrm{~kg} \mathrm{~N} / \mathrm{fed}$} & 50 DFS & 631.4 & bcdefg & 665.8 & $a b c$ \\
\hline & & 70 DFS & 581.3 & fghijklm & 656.4 & abcde \\
\hline & & $50 \& 70$ DFS & 619.5 & bcdefgh & 661.3 & abcd \\
\hline \multirow{9}{*}{ Sakha 5} & \multirow{3}{*}{$30 \mathrm{~kg} \mathrm{~N} / \mathrm{fed}$} & 50 DFS & 380.8 & $\mathrm{t}$ & 416.7 & stu \\
\hline & & 70 DFS & 416.2 & st & 454.9 & rs \\
\hline & & $50 \& 70$ DFS & 389.5 & $\mathrm{t}$ & 446.0 & st \\
\hline & \multirow{3}{*}{$45 \mathrm{~kg} \mathrm{~N} / \mathrm{fed}$} & 50 DFS & 430.5 & rst & 401.1 & $\mathrm{u}$ \\
\hline & & 70 DFS & 413.5 & st & 430.4 & stu \\
\hline & & $50 \& 70$ DFS & 493.7 & $\mathrm{pq}$ & 486.7 & qr \\
\hline & \multirow{3}{*}{$60 \mathrm{~kg} \mathrm{~N} / \mathrm{fed}$} & 50 DFS & 503.7 & opq & 499.6 & $\mathrm{pq}$ \\
\hline & & 70 DFS & 528.7 & Imnop & 513.9 & nopq \\
\hline & & $50 \& 70$ DFS & 516.3 & nopq & 531.6 & nop \\
\hline \multirow{9}{*}{$\begin{array}{l}\text { Strain } \\
541 / G / 1\end{array}$} & \multirow{3}{*}{$30 \mathrm{~kg} \mathrm{~N} / \mathrm{fed}$} & 50 DFS & 403.0 & st & 410.9 & tu \\
\hline & & 70 DFS & 460.3 & qrs & 421.5 & stu \\
\hline & & $50 \& 70$ DFS & 459.5 & qrs & 452.5 & rs \\
\hline & & 50 DFS & 405.9 & st & 455.2 & rs \\
\hline & $45 \mathrm{~kg} \mathrm{~N} / \mathrm{fed}$ & 70 DFS & 503.7 & opq & 486.5 & $\mathrm{qr}$ \\
\hline & & $50 \& 70$ DFS & 515.4 & nopq & 501.7 & opq \\
\hline & & 50 DFS & 506.3 & opq & 534.7 & nop \\
\hline & $60 \mathrm{~kg} \mathrm{~N} / \mathrm{fed}$ & 70 DFS & 484.6 & pqr & 553.1 & $\mathrm{klmn}$ \\
\hline & & $50 \& 70$ DFS & 523.1 & mnop & 549.5 & Imn \\
\hline & & 50 DFS & 488.8 & $\mathrm{pq}$ & 501.2 & opq \\
\hline & $30 \mathrm{~kg} \mathrm{~N} / \mathrm{fed}$ & 70 DFS & 572.3 & ghijklmn & 541.5 & $\mathrm{mno}$ \\
\hline & & $50 \& 70$ DFS & 571.9 & ghijklmn & 595.0 & hij \\
\hline & & 50 DFS & 583.8 & fghijklm & 646.9 & abcdefg \\
\hline Sakha 3 & $45 \mathrm{~kg} \mathrm{~N} / \mathrm{fed}$ & 70 DFS & 633.7 & bcdefg & 648.0 & abcdefg \\
\hline & & $50 \& 70$ DFS & 660.0 & $a b c$ & 633.5 & bcdefgh \\
\hline & & 50 DFS & 658.1 & abcd & 671.3 & $a b$ \\
\hline & $60 \mathrm{~kg} \mathrm{~N} / \mathrm{fed}$ & 70 DFS & 625.3 & bcdefgh & 660.1 & abcde \\
\hline & & $50 \& 70$ DFS & 653.4 & abcde & 648.8 & abcdef \\
\hline & & 50 DFS & 531.5 & klmnop & 531.3 & nop \\
\hline & $30 \mathrm{~kg} \mathrm{~N} / \mathrm{fed}$ & 70 DFS & 509.0 & opq & 533.3 & nop \\
\hline & & $50 \& 70$ DFS & 607.7 & bcdefghi & 589.6 & $\mathrm{ijk}$ \\
\hline & & 50 DFS & 668.9 & $a b$ & 624.8 & cdefghi \\
\hline Strain & $45 \mathrm{~kg} \mathrm{~N} / \mathrm{fed}$ & 70 DFS & 667.5 & $a b$ & 650.3 & abcdef \\
\hline $620 / 3 / 5$ & & $50 \& 70$ DFS & 643.9 & abcdef & 619.4 & defghij \\
\hline & & 50 DFS & 655.9 & abcd & 669.8 & $a b$ \\
\hline & $60 \mathrm{~kg} \mathrm{~N} / \mathrm{fed}$ & 70 DFS & 662.2 & $a b$ & 679.9 & $a$ \\
\hline & & $50 \& 70$ DFS & 701.3 & $a$ & 689.0 & $a$ \\
\hline
\end{tabular}

Means followed by the same letter within columns are not significantly different at $P<0.05$ using Duncan`s multiple range test. 
Table 8: Seed yield per plant of flax as affected by the interaction among genotype, nitrogen fertilizer level and time of foliar spraying with potassium during 2013/2014 and 2014/2015 seasons

\begin{tabular}{|c|c|c|c|c|c|c|}
\hline \multirow{2}{*}{\multicolumn{2}{|c|}{ Treatment }} & & \multicolumn{4}{|c|}{ Seed yield (g/plant) } \\
\hline & & & \multicolumn{2}{|c|}{$2013 / 2014$} & \multicolumn{2}{|c|}{$2014 / 2015$} \\
\hline \multirow{9}{*}{ Sakha 1} & \multirow{3}{*}{$30 \mathrm{~kg} \mathrm{~N} / \mathrm{fed}$} & 50 DFS & 0.247 & st & 0.273 & st \\
\hline & & 70 DFS & 0.297 & pqrst & 0.267 & pqrst \\
\hline & & $50 \& 70$ DFS & 0.340 & nopqr & 0.370 & nopqr \\
\hline & \multirow{3}{*}{$45 \mathrm{~kg} \mathrm{~N} / \mathrm{fed}$} & 50 DFS & 0.420 & jklmn & 0.410 & jklmn \\
\hline & & 70 DFS & 0.397 & klmno & 0.433 & klmno \\
\hline & & $50 \& 70$ DFS & 0.470 & $\mathrm{ijk}$ & 0.503 & ijk \\
\hline & \multirow{3}{*}{$60 \mathrm{~kg} \mathrm{~N} / \mathrm{fed}$} & 50 DFS & 0.500 & ghij & 0.490 & ghij \\
\hline & & 70 DFS & 0.560 & defgh & 0.553 & defgh \\
\hline & & $50 \& 70$ DFS & 0.657 & $a b c$ & 0.587 & $a b c$ \\
\hline \multirow{9}{*}{$\begin{array}{l}\text { Strain } \\
402 / 1\end{array}$} & \multirow{3}{*}{$30 \mathrm{~kg} \mathrm{~N} / \mathrm{fed}$} & 50 DFS & 0.307 & pqrst & 0.260 & pqrst \\
\hline & & 70 DFS & 0.350 & mnopq & 0.323 & mnopq \\
\hline & & $50 \& 70$ DFS & 0.367 & mnop & 0.420 & mnop \\
\hline & \multirow{3}{*}{$45 \mathrm{~kg} \mathrm{~N} / \mathrm{fed}$} & 50 DFS & 0.433 & $\mathrm{jklm}$ & 0.430 & $\mathrm{jklm}$ \\
\hline & & 70 DFS & 0.423 & jklmn & 0.420 & jklmn \\
\hline & & $50 \& 70$ DFS & 0.573 & cdefg & 0.503 & cdefg \\
\hline & \multirow{3}{*}{$60 \mathrm{~kg} \mathrm{~N} / \mathrm{fed}$} & 50 DFS & 0.640 & abcd & 0.627 & abcd \\
\hline & & 70 DFS & 0.617 & bcde & 0.600 & bcde \\
\hline & & $50 \& 70$ DFS & 0.703 & $a$ & 0.643 & $a$ \\
\hline \multirow{9}{*}{ Sakha 5} & \multirow{3}{*}{$30 \mathrm{~kg} \mathrm{~N} / \mathrm{fed}$} & 50 DFS & 0.330 & opqrs & 0.273 & opqrs \\
\hline & & 70 DFS & 0.350 & mnopq & 0.340 & mnopq \\
\hline & & $50 \& 70$ DFS & 0.397 & klmno & 0.413 & klmno \\
\hline & \multirow{3}{*}{$45 \mathrm{~kg} \mathrm{~N} / \mathrm{fed}$} & 50 DFS & 0.500 & ghij & 0.503 & ghij \\
\hline & & 70 DFS & 0.523 & fghi & 0.533 & fghi \\
\hline & & $50 \& 70$ DFS & 0.700 & $a$ & 0.647 & $a$ \\
\hline & \multirow{3}{*}{$60 \mathrm{~kg} \mathrm{~N} / \mathrm{fed}$} & 50 DFS & 0.717 & $a$ & 0.660 & $a$ \\
\hline & & 70 DFS & 0.720 & $a$ & 0.680 & $a$ \\
\hline & & $50 \& 70$ DFS & 0.723 & $a$ & 0.693 & $a$ \\
\hline \multirow{9}{*}{$\begin{array}{l}\text { Strain } \\
541 / G / 1\end{array}$} & \multirow{3}{*}{$30 \mathrm{~kg} \mathrm{~N} / \mathrm{fed}$} & 50 DFS & 0.340 & nopqr & 0.280 & nopqr \\
\hline & & 70 DFS & 0.357 & mnop & 0.327 & mnop \\
\hline & & $50 \& 70$ DFS & 0.423 & jklmn & 0.410 & jklmn \\
\hline & & 50 DFS & 0.457 & $\mathrm{ijkl}$ & 0.443 & $\mathrm{ijkl}$ \\
\hline & $45 \mathrm{~kg} \mathrm{~N} / \mathrm{fed}$ & 70 DFS & 0.437 & $\mathrm{jklm}$ & 0.463 & $\mathrm{jklm}$ \\
\hline & & $50 \& 70$ DFS & 0.573 & cdefg & 0.547 & cdefg \\
\hline & & 50 DFS & 0.540 & efghi & 0.597 & efghi \\
\hline & $60 \mathrm{~kg} \mathrm{~N} / \mathrm{fed}$ & 70 DFS & 0.650 & $a b c$ & 0.640 & $a b c$ \\
\hline & & $50 \& 70$ DFS & 0.670 & $a b$ & 0.697 & $a b$ \\
\hline & & 50 DFS & 0.227 & $\mathrm{t}$ & 0.253 & $t$ \\
\hline & $30 \mathrm{~kg} \mathrm{~N} / \mathrm{fed}$ & 70 DFS & 0.247 & st & 0.257 & st \\
\hline & & $50 \& 70$ DFS & 0.303 & pqrst & 0.347 & pqrst \\
\hline & & 50 DFS & 0.340 & nopqr & 0.413 & nopqr \\
\hline Sakha 3 & $45 \mathrm{~kg} \mathrm{~N} / \mathrm{fed}$ & 70 DFS & 0.373 & Imnop & 0.413 & Imnop \\
\hline & & $50 \& 70$ DFS & 0.473 & ijk & 0.473 & ijk \\
\hline & & 50 DFS & 0.477 & hijk & 0.497 & hijk \\
\hline & $60 \mathrm{~kg} \mathrm{~N} / \mathrm{fed}$ & 70 DFS & 0.460 & $\mathrm{ijkl}$ & 0.547 & $\mathrm{ijkl}$ \\
\hline & & $50 \& 70$ DFS & 0.573 & cdefg & 0.600 & cdefg \\
\hline & & 50 DFS & 0.257 & rst & 0.220 & rst \\
\hline & $30 \mathrm{~kg} \mathrm{~N} / \mathrm{fed}$ & 70 DFS & 0.270 & grst & 0.270 & grst \\
\hline & & $50 \& 70$ DFS & 0.373 & Imnop & 0.340 & Imnop \\
\hline & & 50 DFS & 0.417 & jklmno & 0.373 & jklmno \\
\hline Strain & $45 \mathrm{~kg} \mathrm{~N} / \mathrm{fed}$ & 70 DFS & 0.403 & klmno & 0.380 & klmno \\
\hline $620 / 3 / 5$ & & $50 \& 70$ DFS & 0.477 & hijk & 0.437 & hijk \\
\hline & & 50 DFS & 0.480 & hijk & 0.463 & hijk \\
\hline & $60 \mathrm{~kg} \mathrm{~N} / \mathrm{fed}$ & 70 DFS & 0.587 & bcdef & 0.433 & bcdef \\
\hline & & $50 \& 70$ DFS & 0.613 & bcde & 0.553 & bcde \\
\hline
\end{tabular}

Means followed by the same letter within columns are not significantly different at $\mathrm{P}<0.05$ using Duncan`s multiple range test. 
Table 9: Seed yield per feddan of flax as affected by the interaction among genotype, nitrogen fertilizer level and time of foliar spraying with potassium during 2013/2014 and 2014/2015 seasons

\begin{tabular}{|c|c|c|c|c|c|c|}
\hline \multirow{2}{*}{\multicolumn{2}{|c|}{ Treatment }} & & \multicolumn{4}{|c|}{ Seed yield (kg/fed.) } \\
\hline & & & \multicolumn{2}{|c|}{$2013 / 2014$} & \multicolumn{2}{|c|}{$2014 / 2015$} \\
\hline \multirow{9}{*}{ Sakha 1} & \multirow{3}{*}{$30 \mathrm{~kg} \mathrm{~N} / \mathrm{fed}$} & 50 DFS & 633.7 & hij & 649.2 & $f$ \\
\hline & & 70 DFS & 652.0 & ghi & 651.5 & $f$ \\
\hline & & $50 \& 70$ DFS & 668.5 & $\mathrm{fg}$ & 666.7 & $f$ \\
\hline & \multirow{3}{*}{$45 \mathrm{~kg} \mathrm{~N} / \mathrm{fed}$} & 50 DFS & 682.7 & efg & 692.2 & $\mathrm{e}$ \\
\hline & & 70 DFS & 693.0 & ef & 710.3 & de \\
\hline & & $50 \& 70$ DFS & 714.2 & cde & 732.4 & $\mathrm{bc}$ \\
\hline & \multirow{3}{*}{$60 \mathrm{~kg} \mathrm{~N} / \mathrm{fed}$} & 50 DFS & 739.2 & $\mathrm{bc}$ & 728.5 & $\mathrm{~cd}$ \\
\hline & & 70 DFS & 734.8 & bcd & 711.7 & de \\
\hline & & $50 \& 70$ DFS & 612.2 & $\mathrm{jk}$ & 596.1 & hi \\
\hline \multirow{9}{*}{$\begin{array}{l}\text { Strain } \\
402 / 1\end{array}$} & \multirow{3}{*}{$30 \mathrm{~kg} \mathrm{~N} / \mathrm{fed}$} & 50 DFS & 574.4 & $\mathrm{Im}$ & 545.4 & j \\
\hline & & 70 DFS & 610.3 & jk & 579.9 & $\mathrm{i}$ \\
\hline & & $50 \& 70$ DFS & 635.9 & hij & 595.1 & hi \\
\hline & \multirow{3}{*}{$45 \mathrm{~kg} \mathrm{~N} / \mathrm{fed}$} & 50 DFS & 671.1 & $\mathrm{fg}$ & 605.7 & $\mathrm{~h}$ \\
\hline & & 70 DFS & 659.5 & gh & 627.6 & $\mathrm{~g}$ \\
\hline & & $50 \& 70$ DFS & 705.9 & de & 692.7 & $\mathrm{e}$ \\
\hline & \multirow{3}{*}{$60 \mathrm{~kg} \mathrm{~N} / \mathrm{fed}$} & 50 DFS & 704.1 & de & 698.5 & $\mathrm{e}$ \\
\hline & & 70 DFS & 600.2 & $\mathrm{kl}$ & 707.8 & $\mathrm{e}$ \\
\hline & & $50 \& 70$ DFS & 760.6 & $a b$ & 748.2 & $a b$ \\
\hline \multirow{9}{*}{ Sakha 5} & \multirow{3}{*}{$30 \mathrm{~kg} \mathrm{~N} / \mathrm{fed}$} & 50 DFS & 489.6 & pqrs & 394.2 & $x y$ \\
\hline & & 70 DFS & 442.6 & uvw & 404.1 & $w x$ \\
\hline & & $50 \& 70$ DFS & 494.4 & opqr & 434.3 & tu \\
\hline & \multirow{3}{*}{$45 \mathrm{~kg} \mathrm{~N} / \mathrm{fed}$} & 50 DFS & 500.5 & opqr & 454.5 & qrs \\
\hline & & 70 DFS & 524.4 & no & 473.1 & opq \\
\hline & & $50 \& 70$ DFS & 549.2 & $\mathrm{mn}$ & 501.4 & Imn \\
\hline & \multirow{3}{*}{$60 \mathrm{~kg} \mathrm{~N} / \mathrm{fed}$} & 50 DFS & 556.7 & $\mathrm{~m}$ & 541.1 & j \\
\hline & & 70 DFS & 749.8 & $a b$ & 587.4 & hi \\
\hline & & $50 \& 70$ DFS & 779.3 & $a$ & 763.2 & $a$ \\
\hline \multirow{9}{*}{$\begin{array}{l}\text { Strain } \\
541 / G / 1\end{array}$} & \multirow{3}{*}{$30 \mathrm{~kg} \mathrm{~N} / \mathrm{fed}$} & 50 DFS & 456.6 & stu & 394.2 & $x y$ \\
\hline & & 70 DFS & 474.3 & qrstu & 394.9 & $x y$ \\
\hline & & $50 \& 70$ DFS & 490.6 & pqr & 422.0 & uvw \\
\hline & & 50 DFS & 496.4 & opqr & 435.0 & stu \\
\hline & $45 \mathrm{~kg} \mathrm{~N} / \mathrm{fed}$ & 70 DFS & 509.7 & op & 440.4 & rstu \\
\hline & & $50 \& 70$ DFS & 551.8 & $\mathrm{mn}$ & 472.8 & opq \\
\hline & & 50 DFS & 578.8 & $\mathrm{Im}$ & 474.6 & op \\
\hline & $60 \mathrm{~kg} \mathrm{~N} / \mathrm{fed}$ & 70 DFS & 622.6 & ijk & 495.5 & $\mathrm{mn}$ \\
\hline & & $50 \& 70$ DFS & 654.4 & gh & 517.7 & $\mathrm{kl}$ \\
\hline & & 50 DFS & 401.9 & $x y$ & 406.7 & vwx \\
\hline & $30 \mathrm{~kg} \mathrm{~N} / \mathrm{fed}$ & 70 DFS & 412.2 & wxy & 424.7 & tuv \\
\hline & & $50 \& 70$ DFS & 418.1 & WX & 442.5 & rst \\
\hline & & 50 DFS & 440.8 & uvw & 398.8 & $x y$ \\
\hline Sakha 3 & $45 \mathrm{~kg} \mathrm{~N} / \mathrm{fed}$ & 70 DFS & 419.7 & vwX & 465.8 & opq \\
\hline & & $50 \& 70$ DFS & 467.3 & rstu & 475.9 & op \\
\hline & & 50 DFS & 467.6 & rstu & 483.4 & no \\
\hline & $60 \mathrm{~kg} \mathrm{~N} / \mathrm{fed}$ & 70 DFS & 473.9 & qrstu & 513.8 & $\mathrm{Im}$ \\
\hline & & $50 \& 70$ DFS & 502.3 & opq & 534.3 & $\mathrm{jk}$ \\
\hline & & 50 DFS & 386.0 & $y$ & 344.2 & $z$ \\
\hline & $30 \mathrm{~kg} \mathrm{~N} / \mathrm{fed}$ & 70 DFS & 393.7 & $x y$ & 348.5 & $z$ \\
\hline & & $50 \& 70$ DFS & 420.7 & vwx & 382.3 & $y$ \\
\hline & & 50 DFS & 441.3 & uvw & 393.9 & $x y$ \\
\hline Strain & $45 \mathrm{~kg} \mathrm{~N} / \mathrm{fed}$ & 70 DFS & 451.4 & tuv & 398.7 & $x y$ \\
\hline $620 / 3 / 5$ & & $50 \& 70$ DFS & 472.2 & qrstu & 426.2 & tu \\
\hline & & 50 DFS & 467.7 & rstu & 439.7 & rstu \\
\hline & $60 \mathrm{~kg} \mathrm{~N} / \mathrm{fed}$ & 70 DFS & 478.4 & pqrst & 441.6 & rstu \\
\hline & & $50 \& 70$ DFS & 494.5 & opqr & 459.0 & pqr \\
\hline
\end{tabular}

Means followed by the same letter within columns are not significantly different at $P<0.05$ using Duncan`s multiple range test. 


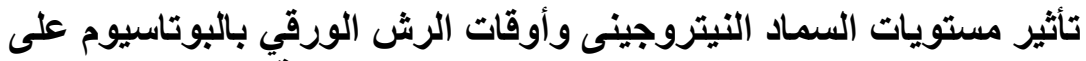

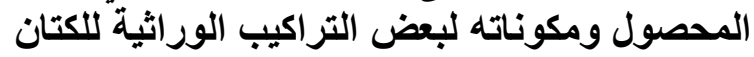

مجدى حليم إبراهيم ، محمد السيد قنيير² ، عادل يوسف رجب1 ووليد فوزى محمد على جالو2

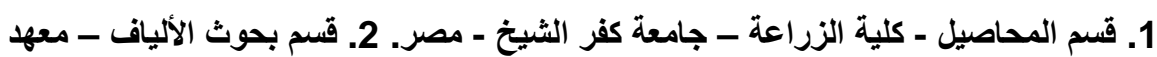

بحوث المحاصيل الحقلية ـ مركز البحوث الزئ الزراعية ـ الجيزة ـ مصر.

أجريت هذه الدراسة في المزرعة البحثنية بكلية الزراعة، جامعة كفر الثيخ، مصر ، خلادل

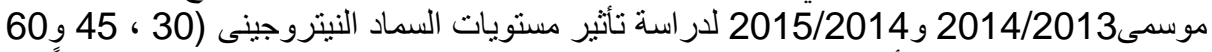

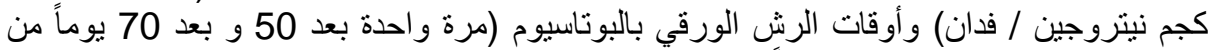

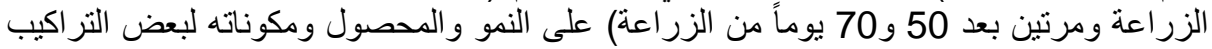

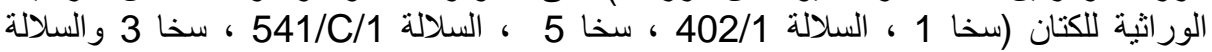
620/3/5). وقد أجريت التجربة في تصميم القطع المنشقة مرتين فى أربع مكررات. حيثة حيث تم

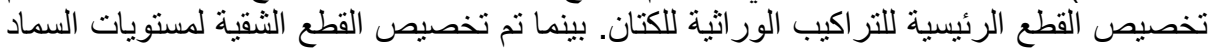

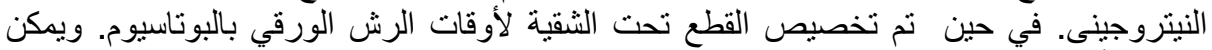
تلخيص أهم النتائج المتحصل هين عليها كما يلي:

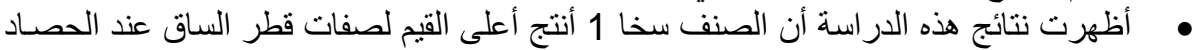

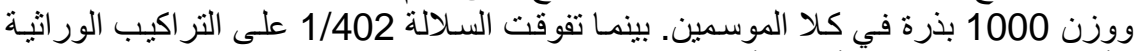

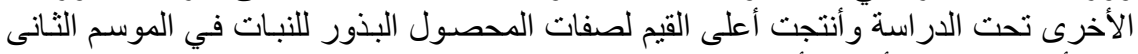

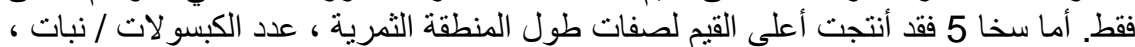

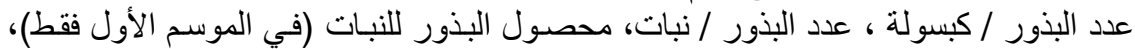

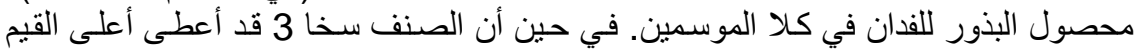

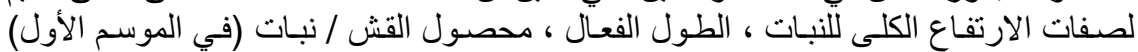

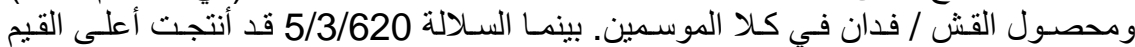

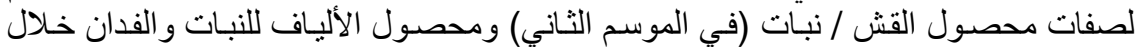

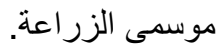

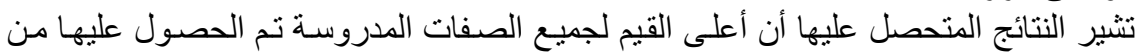

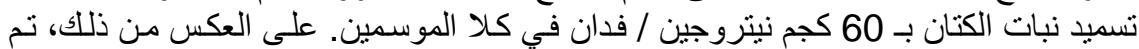

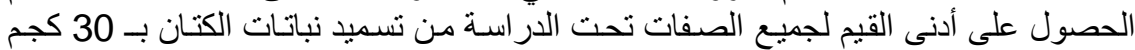

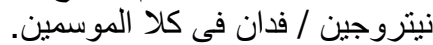

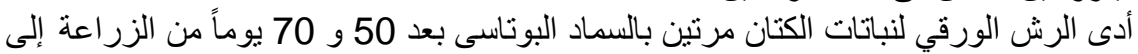

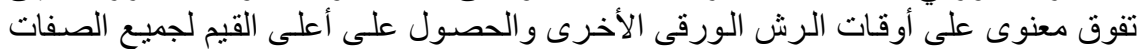

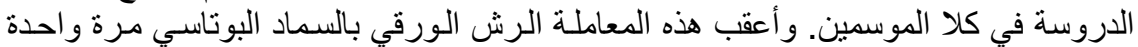

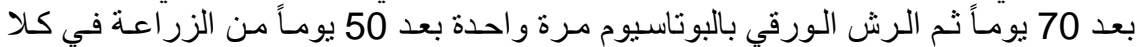

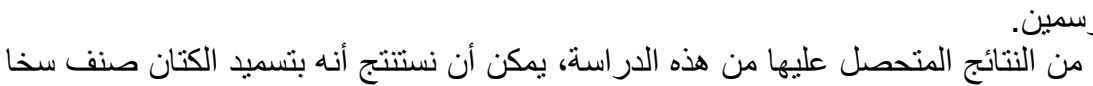

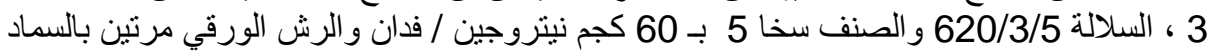

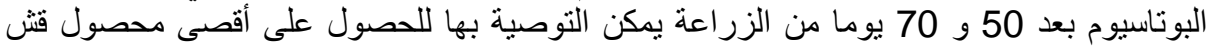
و ألياف وبذور وذلائك تحت نفس الظروف لهذا. 